\title{
DAMPAK PERUBAHAN FISIOLOGI DAN BIOKIMIA BENIH EBONI (Diospyros celebica Bakh.) SELAMA PENYIMPANAN
}

\author{
(The Impact of Physiological and Biochemical Changes of Eboni \\ (Diospyros celebica Bakh.) Seeds During Storage) \\ Naning Yuniarti, Dida Syamsuwida, Aam Aminah ${ }^{1)}$ \\ ${ }^{1)}$ Balai Penelitian Teknologi Perbenihan Tanaman Hutan \\ Jl. Pakuan Ciheuleut PO.Box 105 Bogor \\ Telp./Fax. (0251) 8327768 \\ email : naningbtp@yahoo.co.id
}

Naskah masuk : 28 Mei 2012; Naskah diterima : 30 Mei 2013

\begin{abstract}
The research was objected to determine the impact on biochemical and physiological changes of eboni (Diospyros celebica Bakh.) seeds during storage. Completely randomized design was used in this trial with two treatments, i.e storage room condition and storage periods. The results showed that physiological changes of the seeds during storage decreased their germination percentage and seed moisture content. Biochemical changes as indicated by the increase of fat and protein contents, as well as reduction of carbohydrat content following the period of drying and storage were observed. Storing the seeds in an Air-Conditioned room could keep germination percentages at $61,94 \%$ with the moisture content at 46,69\% for as long as 8 weeks. Based on physiological and biochemical responses, eboni seeds could be classified as recalcitrant type.
\end{abstract}

Keywords: Seed, biochemistry, physiology, storage, viability

\begin{abstract}
ABSTRAK
Eboni (Diospyros celebica Bakh.) merupakan jenis tanaman yang potensial untuk dikembangkan pada pembangunan hutan tanaman. Benih bermutu tinggi diperlukan dalam program pengembangan jenis ini dan penyimpanan benih tidak dapat dihindari berkaitan dengan penyediaan benih. Penyimpanan benih eboni ditujukan untuk mempertahankan viabilitas benih agar tetap tinggi. Tujuan penelitian adalah untuk mengetahui dampak perubahan kandungan biokimia dan fisiologis benih eboni selama penyimpanan. Rancangan percobaan yang digunakan dalam penelitian ini adalah Rancangan Acak Lengkap pola Faktorial dengan perlakuan faktor ruang simpan dan periode penyimpanan. Hasil penelitian menunjukkan perubahan fisiologis benih eboni selama penyimpanan mengakibatkan adanya penurunan nilai daya berkecambah dan kadar air benih ; perubahan biokimia benih eboni selama penyimpanan menunjukkan adanya peningkatan kandungan lemak dan protein serta penurunan kandungan karbohidrat seiring dengan lamanya pengeringan dan penyimpanan; penyimpanan benih eboni di ruang simpan AC dapat mempertahankan viabilitas benih selama 8 minggu, dengan daya berkecambahnya hingga $61,94 \%$ dengan kadar air 46,69 \%. Berdasarkan reaksi fisiologis dan biokimia yang terjadi, maka benih eboni dapat dikatagorikan sebagai benih rekalsitran.
\end{abstract}

Kata kunci : Benih, biokimia, fisiologi, penyimpanan, viabilitas

\section{PENDAHULUAN}

Peningkatan jumlah dan mutu benih perlu diperhatikan untuk menjamin pengadaan bahan tanaman dalam program penanaman. Peningkatan tersebut diantaranya adalah melalui waktu yang tepat dalam pengumpulan benih, penanganan benih yang baik dan benar serta penyimpanan yang aman. Apabila langkah-langkah ini diikuti maka program penanaman akan lebih berhasil.
Eboni (Diospyros celebica Bakh.) adalah satu jenis pohon hutan yang mempunyai nilai ekonomi tinggi mengingat kayunya yang sangat baik untuk mebel mewah, perpatungan, ukiran, kipas, barang bubutan, alat-alat dekoratif, badan sikat, venire mewah, alat musik tiup dan lain-lain. Pengembangan jenis ini perlu ditingkatkan mengingat potensi dan manfaat yang dimilikinya.

Secara alami benih eboni mengalami kemunduran dengan bertambahnya waktu. Dengan demikian penyimpanan jenis benih tersebut secara 
aman ditujukan untuk mempertahankan viabilitas benih tetap tinggi hingga saat benih digunakan untuk pertanaman. Menurut Sadjad (1977), dua hal yang berkaitan dengan proses kemunduran benih selama periode penyimpanan adalah kemunduran yang bersifat kronologis yang berkaitan dengan unsur waktu dan kemunduran fisiologis yang disebabkan oleh berbagai faktor lingkungan. Selanjutnya Sadjad (1999) mengemukakan bahwa kemunduran benih adalah mundurnya mutu fisiologis benih yang dapat menyebabkan perubahan menyeluruh di dalam benih baik fisik, fisiologis maupun kimiawi yang mengakibatkan menurunnya viabilitas benih.

Kemunduran benih rekalsitran akibat faktor internal maupun eksternal ditandai dengan perkecambahan dan vigor bibit yang rendah. (Sadjad, 1977). Indikasi biokimia dalam benih yang mengalami kemunduran adalah terjadinya perubahan aktivitas enzim, perubahan laju respirasi, perubahan dalam cadangan makanan, perubahan di dalam membran, kerusakan khromosom dan akumulasi bahan toksin (Baki \& Anderson, 1970).

Temperatur dan kelembaban yang tinggi di daerah tropika menyebabkan benih mengalami kemunduran yang cepat selama penyimpanan. Dengan demikian, penyimpanan merupakan aspek yang penting bagi benih rekalsitran untuk dapat mempertahankan viabilitasnya dalam kurun waktu tertentu. Beberapa faktor yang mempengaruhi viabilitas benih selama penyimpanan antara lain suhu, kadar air benih, kelembaban relatif dan gas oksigen. Perubahan kondisi selama penyimpanan dapat menyebabkan perubahan laju respirasi. Laju respirasi terus meningkat bila suhu lingkungan meningkat sampai suatu saat lajunya dihambat karena terjadinya hal seperti inaktivasi enzim, kehabisan cadangan nutrisi atau oksigen atau karena karbondioksida terakumulasi, hingga mencapai tingkat yang menghambat. Selama penyimpanan, benih yang mengandung banyak lemak lebih cepat rusak dibandingkan dengan benih yang banyak mengandung pati atau protein (Sudjindro, 1994). Dengan mengetahui kandungan biokimia tersebut, maka potensi benih dapat diprediksi sehingga teknik penyimpanan atau pengujian yang tepat dapat ditetapkan bagi benih tersebut.

Sehubungan dengan kenyataan di atas maka perlu dilakukan penelitian mengenai dampak perubahan fisiologi dan biokimia yang terjadi pada benih tanaman hutan khususnya eboni untuk dapat menentukan kualitas benih tersebut sehubungan dengan teknik penyimpanan yang dilaku- kan, sehingga viabilitas benih dapat dipertahankan hingga saat penanaman.

Tujuan penelitian ini adalah untuk mengetahui dampak perubahan kandungan fisiologis dan biokimia benih eboni (Diospyros celebica $B a k h$.) selama penyimpanan.

\section{METODE PENELITIAN}

\section{A. Lokasi dan Waktu Penelitian}

Penelitian dilaksanakan di Laboratorium Balai Penelitian dan Pengembangan Teknologi Perbenihan dan Laboratorium Ekofisiologi Balai Penelitian Tanaman Rempah dan Obat, Bogor.

\section{B. Bahan dan Alat}

Bahan dan alat yang digunakan dalam penelitian ini adalah benih eboni yang dikumpulkan dari KHDT Cikampek, Badan Litbang Kehutanan di Desa Kamojing, Kecamatan Cikampek, Kabupaten Karawang, Provinsi Jawa Barat, media perkecambahan, gelas ukur, bak kecambah, peralatan pengujian kadar air, pengukur suhu dan kelembaban, peralatan analisa biokimia, ruang penyimpanan (refrigerator, suhu kamar, AC), wadah kantong plastik, label, dan alat tulis.

\section{Prosedur Kerja}

Kegiatan penelitian ini terdiri dari beberapa tahapan kegiatan yang meliputi :

1. Pencarian sumber benih dan pengumpulan buah

Pencarian sumber benih ditujukan pada lokasi yang ada tegakan eboni. Buah dikumpulkan dari pohon induk terpilih dengan cara : (1) Memanjat dengan menggunakan tangga, buah dipetik langsung atau memotong dahan yang berbuah menggunakan galah berkait dan (2) Mengumpulkan dari bawah dengan menggunakan galah terutama untuk pohon yang tidak terlalu tinggi.

2. Penentuan masak fisiologis dan ekstraksi benih

Buah yang telah mencapai masak fisiologis ditandai dari warna buah dan bentuk buah. Buah eboni masak dicirikan dengan kulit buah berwarna hijau kecoklatan berbintikbintik kuning (Kurniaty, 2001). Ekstraksi benih dilakukan dengan cara manual, yaitu buah dibelah pakai tangan karena buah yang telah masak kulitnya sangat lunak. 
3. Pengukuran kadar air

Kadar air benih diukur dengan metoda oven dan dihitung berdasarkan berat basah (ISTA, 1996).

4. Perlakuan

Tempat dan waktu penyimpanan benih merupakan perlakuan dalam penelitian ini. Benih disimpan secara konvensional pada ruang kamar, refrigerator dan ruang AC dengan interval penyimpanan setiap 4 minggu selama 8 minggu. Sebelum benih disimpan dalam ruang simpan, benih dimasukkan dalam kantong plastik dengan ditambah satu macam media simpan yaitu serbuk sabut kelapa sebagai osmoconditioning (Tompsett, 1992).

5. Pengujian benih

Pengujian benih diperlukan untuk menilai mutu fisiologis dan biokimia benih yang diteliti, metoda yang digunakan untuk uji fisiologis adalah pengujian di bedeng perkecambahan dengan menggunakan media campuran pasir dan tanah $(\mathrm{v}: \mathrm{v}=1: 1)$.

6. Rancangan Penelitian

Rancangan penelitian yang digunakan dalam penelitian ini adalah Rancangan Acak Lengkap (RAL) yang disusun secara faktorial, dengan menggunakan faktor ruang simpan dan faktor lama penyimpanan sebagai berikut:

$\mathrm{A}=$ Faktor ruang simpan

A1 : suhu kamar $\left(28-29^{\circ} \mathrm{C}\right)$,

A2 : suhu refrigerator $\left(6-7^{\circ} \mathrm{C}\right)$,

$\mathrm{A} 3$ : suhu ruang $\mathrm{AC}\left(18-20^{\circ} \mathrm{C}\right)$.

$\mathrm{B}=$ Faktor lama penyimpanan

B1 : 0 minggu (kontrol),

B2 : 4 minggu,

B3 : 8 minggu.

Model linier yang digunakan adalah sebagai berikut:

$\mathrm{Y}_{\mathrm{ijk}}=\mu+\mathrm{A}_{\mathrm{i}}+\mathrm{B}_{\mathrm{j}}+\mathrm{AB}_{\mathrm{ij}}+\boldsymbol{\varepsilon}_{\mathrm{ij}, \mathrm{k}}$

Keterangan :

Yijk $=$ Nilai hasil pengamatan akibat pengaruh ruang simpan ke-i, lama penyimpanan ke-j, dan ulangan ke-k

$\mu=$ Nilai rata-rata umum

$\mathrm{A}_{\mathrm{i}}=$ Pengaruh ruang simpan ke-i

$\mathrm{B}_{\mathrm{j}} \quad=$ Pengaruh lama penyimpanan ke-k

$\mathrm{AB}_{\mathrm{ij}}=$ Nilai akibat pengaruh interaksi ruang simpan ke-i dan lama penyimpanan ke-j,

$\varepsilon_{i j k}=$ Kesalahan percobaan akibat penga-ruh interaksi ruang simpan ke-i, lama penyimpanan ke-j, dan ulangan ke k
Ulangan yang digunakan adalah sebanyak 3 kali. Setiap unit perlakuan terdiri dari 50 benih. Data yang diperoleh dianalisa keragamannya dan diuji perbedaannya dengan uji BNT (Beda Nyata Terkecil).

Respon yang diamati untuk reaksi fisiologi yaitu:

1. Daya berkecambah(DB)

Yaitu banyaknya persentase kecambah normal pada pengamatan selama 30 hari setelah tanam (hst), dengan persamaan sebagai berikut:

$\mathrm{DB}=\frac{\text { Jumlah kecambah normal }}{\text { Jumlah benih yang ditanam }} \times 100 \%$

2. Kadar Air Benih

Benih seberat 10 gr masing-masing diiris kecil, kemudian ditimbang setelah itu dikeringkan dalam oven $103{ }^{\circ} \mathrm{C}$ selama 17 jam (ISTA, 1985). Kadar air dihitung berdasarkan berat basah benih.

3. Parameter untuk reaksi biokimia (awal dan akhir penelitian) yaitu :

a. Kandungan lemak

Lemak benih ditentukan dengan cara ekstraksi soxhlet dan asam lemak bebas ditentukan dengan cara titrasi (Apriyantono etal., 1989).

b. Kandungan karbohidrat

Kandungan pati ditentukan dengan cara absorban (Apriyantono et al., 1989).

c. Kandungan total protein

Total protein ditentukan dengan metode Stocheck (1990).

\section{HASIL DAN PEMBAHASAN}

\section{A. Hasil Penelitian}

\section{Pengaruh penyimpanan terhadap peruba- han fisiologis (Kadar Air dan Daya Berke- cambah)}

Nilai rata-rata kadar air dan daya berkecambah benih eboni sebelum disimpan (0 minggu/ kontrol) adalah kadar air $74,32 \%$ dan daya berkecambah 94,67\%. Ringkasan Hasil sidik ragam pengaruh perlakuan penyimpanan terhadap kadar air dan daya berkecambah benih eboni disajikan di Tabel 1.

Pada Tabel 1 terlihat bahwa interaksi antara ruang simpan dan lama penyimpanan menunjukkan pengaruh yang nyata terhadap nilai kadar air 
Tabel(Table) 1. Ringkasan analisa sidik ragam pengaruh terhadap nilai kadar air dan daya berkecambah benih eboni (Summary of analysis of variance effect on moisture content and seed germination eboni)

\begin{tabular}{|c|c|c|c|c|c|}
\hline \multirow[b]{2}{*}{$\begin{array}{l}\text { Sumber keragaman } \\
\text { (Source of Variance) }\end{array}$} & \multirow{2}{*}{$\begin{array}{l}\text { Derajat } \\
\text { bebas } \\
\text { (Degree of } \\
\text { freedom) }\end{array}$} & \multicolumn{2}{|c|}{$\begin{array}{l}\text { Kuadrat Tengah } \\
\text { (Mean of Square) }\end{array}$} & \multicolumn{2}{|c|}{ F-Hitung (F-Calculation) } \\
\hline & & $\begin{array}{l}\text { Kadar air } \\
\text { (Moisture } \\
\text { content) }\end{array}$ & $\begin{array}{c}\text { Daya } \\
\text { berkecambah } \\
\text { (Germination } \\
\text { percentage) }\end{array}$ & $\begin{array}{l}\text { Kadar air } \\
\text { (Moisture } \\
\text { content) }\end{array}$ & $\begin{array}{c}\text { Daya } \\
\text { berkecambah } \\
\text { (Germination } \\
\text { percentage) }\end{array}$ \\
\hline $\begin{array}{l}\text { Perlakuan } \\
\text { (Treatment) }\end{array}$ & & & & & \\
\hline $\begin{array}{l}\text { Ruang Simpan } \\
\text { (Room of Storage) (A) }\end{array}$ & 2 & 180,59 & $3.600,00$ & $60,20 * *$ & $675,42 * *$ \\
\hline $\begin{array}{l}\text { Lama Penyimpanan } \\
\text { (Long of Storage) (B) }\end{array}$ & 2 & 10,11 & 900,00 & $3,77^{*}$ & $168,86^{* *}$ \\
\hline $\begin{array}{l}\text { Interaksi (Interaction) } \\
\mathrm{A} \& \mathrm{~B}\end{array}$ & 4 & 98,60 & $2.550,00$ & $32,87 * *$ & $478,42 * *$ \\
\hline Sisa (Residual) & 18 & 3,00 & 5,33 & & \\
\hline Jumlah (Total) & 26 & & & & \\
\hline
\end{tabular}

Keterangan(Remarks) : **= Nyata pada taraf 1\% (Significant at 1\% level)

$*=$ Nyata pada taraf $5 \%$ (Significant at $5 \%$ level)

tn = Tidak berpengaruh nyata (No significant effect)

Tabel(Table) 2. Nilai rata-rata kadar air dan daya berkecambah benih eboni selama penyimpanan (The average value of moisture content and eboni seed germination during storage)

\begin{tabular}{cccc}
\hline $\begin{array}{c}\text { Lama penyimpanan } \\
\text { (Storage period) } \\
\text { Minggu (Week) }\end{array}$ & $\begin{array}{c}\text { Ruang simpan } \\
\text { (Room of storage) }\end{array}$ & $\begin{array}{c}\text { Kadar air (\%) } \\
\text { (Moisture content) }\end{array}$ & $\begin{array}{c}\text { Daya berkecambah (\%) } \\
\text { (Percentage of germination) }\end{array}$ \\
\hline 4 & Suhu Kamar & $60,89 \mathrm{e}$ & $74,58 \mathrm{~d}$ \\
& Suhu Refrigerator & $54,37 \mathrm{~d}$ & $64,88 \mathrm{c}$ \\
8 & Suhu AC & $66,51 \mathrm{f}$ & $71,48 \mathrm{e}$ \\
\hline & Suhu Kamar & $40,67 \mathrm{a}$ & $54,75 \mathrm{~b}$ \\
& Suhu Refrigerator & $45,19 \mathrm{~b}$ & $34,97 \mathrm{a}$ \\
\hline
\end{tabular}

Keterangan(Remarks): Angka-angka yang diikuti oleh huruf yang sama menunjukkan tidak adanya perbedaan nyata pada tingkat kepercayaan 95\% (The figures followed by the same letter indicates no significant difference at 95\% confidencelevel)

dan daya berkecambah benih eboni. Uji beda nyata terkecil (BNT) dilakukan untuk melihat perbedaan perlakuan (Tabel2).

2. Pengaruh penyimpanan terhadap perubahan kandungan biokimia (lemak, protein, dan karbohidrat)

Hasil kandungan biokimia yang meliputi protein, lemak dan karbohidrat selama penyimpanan dapat dilihat pada Tabel 3.

\section{B. Pembahasan}

\section{Pengaruh penyimpanan terhadap peruba- han fisiologis (Kadar Air dan Daya Berke- cambah)}

Pada Tabel 2 terlihat bahwa lama penyimpanan benih mulai dari 0 minggu hingga 8 minggu cenderung menurunkan kadar air benih dan daya berkecambah. Dari Tabel diatas terlihat bahwa secara keseluruhan penyimpanan pada kondisi 
Tabel (Table) 3. Nilai rata-rata kandungan lemak, protein dan pati pada benih eboni selama penyimpanan (The average value of fat, protein and starch in the seed during storage eboni)

\begin{tabular}{|c|c|c|c|c|c|c|c|c|c|}
\hline \multirow{2}{*}{$\begin{array}{c}\text { Lama } \\
\text { penyimpanan } \\
\text { (Storage } \\
\text { period) }\end{array}$} & \multicolumn{9}{|c|}{$\begin{array}{c}\text { Ruang simpan } \\
\text { (Room of storage) }\end{array}$} \\
\hline & \multicolumn{3}{|c|}{$\begin{array}{c}\text { Suhu kamar } \\
\text { (Room temperatur) }\end{array}$} & \multicolumn{3}{|c|}{ Refrigerator } & \multicolumn{3}{|c|}{$\mathrm{AC}$} \\
\hline $\begin{array}{l}\text { Minggu } \\
\text { (Week) }\end{array}$ & $\begin{array}{c}\text { Lemak } \\
(F a t) \\
(\%)\end{array}$ & $\begin{array}{c}\text { Protein } \\
(\%)\end{array}$ & $\begin{array}{l}\text { Karbo } \\
\text { hidrat } \\
\text { (Carbo } \\
\text { hydrate) } \\
(\%)\end{array}$ & $\begin{array}{c}\text { Lemak } \\
(F a t) \\
(\%)\end{array}$ & $\begin{array}{c}\text { Protein } \\
(\%)\end{array}$ & $\begin{array}{l}\text { Karbohi } \\
\text { drat } \\
\text { (Carbohy } \\
\text { drate) } \\
(\%)\end{array}$ & $\begin{array}{c}\text { Lemak } \\
(F a t) \\
(\%)\end{array}$ & $\begin{array}{c}\text { Protein } \\
(\%)\end{array}$ & $\begin{array}{c}\text { Karbo } \\
\text { hidrat } \\
\text { (Carbohy } \\
\text { drate) } \\
(\%)\end{array}$ \\
\hline 0 & 0,24 & 2,44 & 12,55 & 0,24 & 2,44 & 12,55 & 0,24 & 2,44 & 12,55 \\
\hline 4 & 0,30 & 5,23 & 6,03 & 0,35 & 6,17 & 9,58 & 0,33 & 6,14 & 8,40 \\
\hline 8 & 1,44 & 6,53 & 5,65 & 0,49 & 7,41 & 7,65 & 0,69 & 7,38 & 7,31 \\
\hline
\end{tabular}

ruang simpan AC memberikan nilai kadar air dan daya berkecambah yang lebih tinggi dibandingkan dengan kondisi ruang simpan kamar dan refrigerator selama penyimpanan 4 dan 8 minggu.

Salah satu indikasi yang dipakai untuk menggolongkan jenis benih tertentu adalah dengan melihat kadar air awalnya. Benih eboni mempunyai kadar air awal sebesar $74,32 \%$. Tingginya kadar air awal jenis ini memperkuat dugaan masuknya jenis eboni kedalam tipe jenis rekalsitran. Daya berkecambah benih eboni cenderung menurun seiring dengan lamanya pengeringan selama 24 jam. Kemunduran benih yang disebabkan penurunan kadar air menurut Sadjad (1999) diindikasikan secara fisiologi dengan adanya perubahan warna benih, tertundanya perkecambahan, menurunnya pertumbuhan berkecambah dan meningkatnya pertumbuhan kecambah abnormal.

Dilihat dari viabilitas benih eboni selama penyimpanan 8 minggu, kadar air dan daya berkecambah benih eboni paling optimal dimiliki benih yang disimpan dalam ruang $\mathrm{AC}$, yaitu benih eboni dapat mempertahankan daya berkecambahnya hingga 61,94\% dengan kadar air $46,69 \%$. Sifat benih eboni selama penyimpanan menunjukkan karakteristik rekalsitran dimana suhu penyimpanan yang dapat mempertahankan viabilitas benih adalah pada suhu ruang AC yaitu antara $20-22{ }^{\circ} \mathrm{C}$. Sedangkan pada suhu kamar $\left(29-30{ }^{\circ} \mathrm{C}\right)$, dan suhu refrigerator $\left(7{ }^{\circ} \mathrm{C}\right)$ benih kurang tahan disimpan. Karakteristik ini sesuai dengan batasan yang dikemukakan oleh Roberts (1973) yaitu suhu penyimpanan benih rekalsitran umumnya hanya sesuai pada $16-20^{\circ} \mathrm{C}$.

\section{Pengaruh penyimpanan terhadap peru- bahan kandungan biokimia (lemak, pro- tein, dan karbohidrat)}

Dari Tabel 3 terlihat bahwa selama penyimpanan benih mulai dari 0 minggu hingga 8 minggu mengakibatkan kandungan lemak dan protein cenderung meningkat. Tetapi dilihat dari kandungan karbohidrat terlihat terjadi penurunan. Peningkatan kandungan lemak dan protein pada benih eboni diduga merupakan mekanisme pertahanan benih selama penyimpanan. Sedangkan penurunan kandungan karbohidrat mengindikasikan penurunan pertahanan benih yang mengakibatkan terjadinya penurunan viabilitas benih. Pada Tabel 3 juga terlihat bahwa selama penyimpanan kandungan lemak, protein dan karbohidrat yang terdapat di ruang simpan $\mathrm{AC}$ memiliki nilai yang lebih tinggi apabila dibandingkan di ruang simpan kamar dan refrigerator.

Peningkatan kandungan lemak dan protein pada benih eboni diduga merupakan mekanisme pertahanan benih selama penyimpanan. Sedangkan penurunan kandungan karbohidrat mengindikasikan penurunan pertahanan benih yang mengakibatkan terjadinya penurunan viabilitas benih.

Ditinjau dari kandungan biokimia yang diukur seperti lemak, protein dan karbohidrat maka benih eboni pada penelitian ini juga menunjukkan gejala kemunduran benih seiring dengan berjalannya waktu (kemunduran kronologis).

Menurut Justice and Bass (1990) kematian benih sering disertai dengan terbentuknya asam lemak seperti terjadi pada benih gandum. Asam lemak biasanya menyebabkan kerusakan pada 
membran karena kemampuan beraksi sebagai deterjen (Priestley, 1986). Pada beberapa kasus ditemukan bahwa meningkatnya kandungan lemak karena adanya jamur selama penyimpanan dalam kondisi lembab seperti terjadi pada benih padi (Priestley, 1986), dan kacang (Agrawal and Siddiqui, 1973).

Kandungan asam lemak yang tinggi di dalam benih juga merupakan indikasi terjadinya proses respirasi yang tinggi yang menyebabkan benih kehilangan energi untuk perkecambahan. Salah satu ciri benih rekalsitran menurut Sudjindro (1994) dalam Suzanna (1999) adalah tingginya kadar lemak yang dikandung, sehingga benih cepat rusak selama penyimpanan.

Selama penyimpanan kandungan protein pada benih eboni juga cenderung meningkat sejalan dengan menurunnya kadar air dan daya berkecambah. Perubahan intensitas dan jenis protein dikontrol oleh DNA yang menyesuaikan dengan aktivitas di dalam benih itu sendiri. Peningkatan kandungan protein ini diduga merupakan mekanisme pertahanan benih terhadap penurunan kadar air dan lama penyimpanan.

Pada kondisi ruang simpan AC dimana benih menunjukkan perkecambahan yang paling baik, ternyata benih memiliki kandungan protein yang lebih tinggi dibandingkan kondisi ruang simpan lainnya. Hal ini juga mengindikasikan adanya pertahanan benih pada kondisi yang optimal. Selain itu, sintesa protein yang spesifik diperlukan untuk mempertahankan dormansi embrio (Gifford, 1993).

Kandungan karbohidrat pada benih eboni menurun selama penyimpanan. Keberadaan karbohidrat dalam benih yang terdiri dari komponen gula (sukrosa) sebagai substrat pembentuk karbohidrat, menunjukkan adanya pertahanan terhadap pengeringan seperti halnya protein. Terjadinya penurunan kandungan karbohidrat mengindikasikan penurunan pertahanan benih artinya terjadi penurunan viabilitas benih. Hal ini ditunjukkan dengan menurunnya daya berkecambah benih eboni selama penyimpanan.

Penelitian mengenai pengaruh penyimpanan terhadap perubahan biokimia benih untuk beberapa jenis tanaman telah dilakukan. Menurut Syamsuwida, et al. (2007) bahwa perubahan biokimia benih gaharu selama penyimpanan menunjukkan adanya peningkatan kandungan karbohidrat, protein dan daya hantar listrik (DHL) serta penurunan kandungan lemak. Hal ini mengindikasikan terjadinya kemunduran kualitas be- nih gaharu. Demikian halnya pada benih antok (Podocarpus sp). Kandungan biokimia yang diukur seperti protein, lemak dan karbohidrat mengalami perubahan setelah penyimpanan yang mengindikasikan kemunduran benih antok (Syamsuwida dan Aam, 2005).

\section{KESIMPULAN}

\section{A. Kesimpulan}

1. Perubahan fisiologis benih eboni selama penyimpanan mengakibatkan adanya penurunan nilai daya berkecambah dan kadar air benih.

2. Perubahan biokimia benih eboni selama penyimpanan menunjukkan adanya peningkatan kandungan lemak dan protein serta penurunan kandungan karbohidrat seiring dengan lamanya penyimpanan.

3. Penyimpanan benih eboni di ruang simpan AC dapat mempertahankan viabilitas benih selama 8 minggu, yaitu dapat mempertahankan daya berkecambahnya hingga $61,94 \%$ dengan kadar air 46,69\%.

4. Berdasarkan reaksi fisiologis dan biokimia yang terjadi, yaitu dari kadar air awal, kandungan biokimia dan sifat penyimpanannya maka benih eboni dapat dikatagorikan sebagai benih rekalsitran.

\section{B. Saran}

Untuk memperkaya hasil penelitian biokimia benih eboni disarankan menambah jumlah parameter diantaranya lemak jenuh untuk mengetahui lebih jauh penurunan mutu benih berkaitan dengan kandungan minyak

\section{DAFTAR PUSTAKA}

Agrawal, P.K and Siddiqui. 1973. Influence of Storage Temperature and Seed Moisture on Germination, Free Fatty acid Content and Leaching of Sugar of Soybean Seed During Storage. Seed Res. (New Delhi). 1:75-82.

Apriyantono, A; D.Fardiaz, N.L Puspitasari; Sedarnawati dan S. Budiyanto. 1989. Petunjuk Laboratorium Analisis Pangan. IPB Press. Bogor.

Baki, A.A.A and J.D Anderson. 1970. Viability and leaching of sugar from germinating Barley. Crop Science, 10:31 - 34.

Gifford, D.J. 1993. Loblolly Pine Seed Dormancy; The Relationship Between Protein, Synthesis 
in The Embryo and Mega Gametophyte and The Loss of Seed Dormancy, In Edward DGW (ed). Dormancy and Barriers to Germination. Proc. Int'l Symp. Of IUFRO Proj. Group P2.04.00 (Seed Problems).

ISTA. 1996. Internasional Rules for seed testing. Proc. Int. Seed Testing Association. 31 (10. Wageningen.

Justice, OL and Bass L.N. 1990. Prinsip Praktek Penyimpanan Benih. Rajawali Press. Jakarta. 446 hal.

Kurniaty, R. 2001. Eboni (Diospyros celebica Bakh). Atlas Benih Tanaman Hutan Indonesia Jilid II. Publikasi Khusus Vol. 2 No. 6. Balai Teknologi Perbenihan. Bogor.

Priestley, A. 1986. Seed Aging : Implications for Seed Storage and Persistence In The Soil Cornell University.

Roberts, E.H. 1973. Predicting the srorage life of seed. Seed Science and Technology 1:499-541.

Sadjad, S. 1977. Penyimpanan benih-benih tanaman pangan. Bahan kuliah Latihan Pola Pertanaman LP3-IRRI. Departemen Agronomi IPB. Bogor.

Sadjad, S. 1999. Parameter Pengujian Vigor Benih dari Komparatif Ke Simulatif. Grasindo. Jakarta.
Stocheck, C.M. 1990. Quantitation of protein. In Deutscher, M.P (eds). Methods in Enzymology. Guide to Protein Purification. Vol. 182. Academic Press, Inc. San Diego, California.

Suzana, E. 1999. Pengaruh penurunan kadar air dan penyimpanan terhadap perubahan fisiologis dan biokimia benih karet (Hevea brasilliensis). Tesis, Program Pasca sarjana. IPB-Bogor. Unpublished.

Sudjindro. 1994. Indikasi kemunduran viabilitas oleh dampak guncangan pada benih kenaf (Hibiscus cannabinus L.). Disertasi Program Pasca Sarjana. IPB.

Syamsuwida, D. dan Aam, A. 2005. Dampak Pengeringan dan Penyimpanan terhadap Perubahan Fisiologi dan Biokimia Benih Antok. Jurnal Penelitian Hutan Tanaman Vol.2 Suplemen No. 2. Pusat Penelitian dan Pengembangan $\mathrm{Hu}-$ tan Tanaman. Badan Penelitian dan Pengembangan Kehutanan. Departemen Kehutanan. Yogyakarta.

Syamsuwida, D. dan Aam, A. 2007. Perubahan Kandungan Lemak, Protein, Pati dan Daya Hantar Listrik pada Benih Gaharu (Aquillaria malaccensis). Jurnal Manajemen Hutan Tropika. Volume XIII, No.2. IPB. Bogor.

Tompsett, P.B. 1992. A review of the literature on storage of dipterocarp seeds. Seed Sci. Technol. 20:251-267. 